\title{
Estimation of Soil Erosion Risk Using the Universal Soil Loss Equation (USLE) and Geo-Information Technology in Oued El Makhazine Watershed, Morocco
}

\author{
Asma Belasri, Abdellah Lakhouili \\ Faculty of Science and Technology, Hassan 1 University, Settat, Morocco \\ Email: belasri.asma@gmail.com \\ Received 6 December 2015; accepted 26 February 2016; published 29* February 2016 \\ Copyright (C) 2016 by authors and Scientific Research Publishing Inc. \\ This work is licensed under the Creative Commons Attribution International License (CC BY). \\ http://creativecommons.org/licenses/by/4.0/ \\ (c) (i) Open Access
}

\begin{abstract}
Soil erosion by water is one of the major threats to soils in the north of Morocco; soil erosion not only decreases agricultural productivity, but also reduces the water availability. In the current study, Oued El Makhazine watershed is selected to estimate annual soil loss using the Universal Soil Loss Equation (USLE), remote sensing (RS) and geographic information system (GIS). GIS data layers including, rainfall erosivity (R), soil erodibility (K), slope length and steepness (LS), cover management (C) and conservation practice (P) factors are computed to determine their effects on average annual soil loss in the area. The resultant map of annual soil erosion shows a maximum soil loss of $735 \mathrm{t} \cdot \mathrm{h}^{-1} \cdot \mathrm{y}^{-1}$, about $65.25 \%\left(1575 \mathrm{~km}^{2}\right)$, of the watershed ranges between 0 and $95 \mathrm{t}^{\mathrm{h}} \mathrm{h}^{-1} \cdot \mathrm{y}^{-1}$. Higher soil losses are observed at higher LS factor area. The spatial erosion maps generate with USLE method, remote sensing and GIS can serve as effective inputs in deriving strategies for land planning and management in the environmentally sensitive mountainous areas.
\end{abstract}

\section{Keywords}

Oued El Makhazine Watershed, Erosion, USLE, Geographic Information System

\section{Introduction}

Soil erosion represents one of the most serious land degradation problems [1]. It is defined as the loosening, dissolving and removal of rock materials from all parts of the earth's surface triggered by a complex interaction process of many factors: natural (climate, topography, soil, vegetation) and anthropogenic (tillage systems, soil 
conservation measures, overgrazing and deforestation) [2] [3].

In the north of Morocco, soil erosion affects negatively agricultural productivity, reduces water infiltration, underground water resources and water availability.

In Morocco, $40 \%$ of land is affected by water erosion [4]. In some parts of the Rif in northern Morocco, erosion rates sometimes reach 30 to $60 \mathrm{t} \cdot \mathrm{ha}^{-1} \cdot \mathrm{y}^{-1}$ [5] [6]. Therefore, dams lose their water capacity initial storage due to their siltation which is estimated to $0.5 \%$ by year [7]. The largest Moroccan dams receive each year approximately 50 million tones of sediment [8], which affects their storage capacity and brings about an annual loss of almost 300 million Dirhams [9].

Due to the intensification of agricultural practices leading to unsustainable farming practices (e.g. inappropriate tillage practices, straw exportation, overgrazing) and specific bioclimatic conditions (e.g. recurring and severe droughts), more than 15 million hectares of the Moroccan agricultural land is under serious threat. As reported by Namr and Mrabet [10], it was estimated that out of 22.7 million hectares potentially exploitable in the Northern part environmental problem worldwide of Morocco, 77\% were exposed to very high erosion risks [11]. The Global Assessment of Human Induced Soil Degradation (GLASOD) survey carried out during the 1980's by the United Nations Environment Programme (UNEP) and the International Soil Reference and Information Centre (ISRIC) established that the severity of human induced degradation had been classified as severe and very severe for more than $20 \%$ of the Moroccan territory [12].

In the Rif Chain (Northern Morocco), several local studies have been applied to evaluate and quantify the erosion risk, especially in the western and central Rif [13] [14].

Therefore, the estimation of erosion factors and exposed areas to soil erosion can be very helpful to identify the increment and the degree of the risks and, finally, to establish conservation measures and soil/water management plans.

In the current study, an effort to predict potential annual soil losses in Oued El Makhazine watershed in Morocco has been conducted using the Universal Soil Loss Equation (USLE) adopted in a GIS environment. It is used for the prediction of sheet erosion depending on the distribution of the aggressiveness of rainfall, the erodibility of soil, topography, land use practices and crop management.

\section{Study Area}

Located in the north of morocco, Oued El Makhazine watershed (Figure 1) covers an area of $2414 \mathrm{Km}^{2}$, and stretches from north latitude $34^{\circ} 45^{\prime} 15.3^{\prime \prime}$ to $35^{\circ} 15^{\prime} 44.6^{\prime \prime}$ west longitude $5^{\circ} 14^{\prime} 32.4^{\prime \prime}$ to $5^{\circ} 51^{\prime} 9.1^{\prime \prime}$, its altitude is between $10 \mathrm{~m}$ and $1677 \mathrm{~m}$.



Figure 1. Oued El Makhazine watershed location map. 
The study area consists west of plains with a very pronounced topography, while to the east the relief becomes more hilly and mountainous. The altitude increases gradually eastward with the first reliefs of the Rif mountain range, this configuration of the relief associated with the presence of the Atlantic Ocean to the west is the main cause of significant rainfall measured in the watershed, the study area receives an annual average rainfall of $1100 \mathrm{~mm}$ [15].

The predominance of impermeable soils in the watershed promotes runoff, which is increased by the slope effect as one progresses eastward.

The vegetation cover of the watershed is defined by the presence of matorral, typical Mediterranean landscapes, with a predominance of forests. Most of the forest cover is at the upper watershed. Downstream, the agriculture is the dominant economic activity in the watershed consists of cultivated plains.

\section{Methodology}

\subsection{Data Processing and USLE Factors Generation}

In recent years, GIS and remote sensing are often used to assess and map water erosion effects. Truthfully, with these modern techniques, it is increasingly exposed the advantages of spatialization methods for assessing and mapping soil erosion over large areas and setting up scenarios for rehabilitation.

Many techniques and studies realized worldwide were done about the evaluation of soil loss. Most of them are using the Universal Soil Loss Equation (USLE) and its revised version (RUSLE) [16]. Others had modified part of the equation to adapt in every country's situation. In this study, we tried to promote the process using the potentials of GIS.

The USLE equation is a product of five input factors (Figure 2) in raster data format: soil erodibility; rainfall erosivity; slope length and steepness; cover management; and support practice. Each factor varies over time and space and depend on other input data. Therefore, soil erosion within each pixel was calculated using the Universal Soil Loss Equation (USLE).

The USLE equation is described as:

$$
A \equiv R \times K \times L S \times C \times P
$$

where $A$ is the computed spatial average of soil loss over a period selected for $R$, usually on yearly basis (t $a^{-1}$ $\left.\cdot \mathrm{y}^{-1}\right) ; R$ is the rainfall erosivity factor $\left(\mathrm{MJ} \cdot \mathrm{mm} \cdot \mathrm{ha}^{-1} \cdot \mathrm{h}^{-1} \cdot \mathrm{y}^{-1}\right) ; K$ is the soil erodibility factor $\left(\mathrm{t} \cdot \mathrm{ha} \cdot \mathrm{h} \cdot \mathrm{ha}^{-1} \cdot \mathrm{MJ}^{-1} \cdot \mathrm{mm}^{-1}\right.$ );



Figure 2. Flowchart of the methodology. 
$L S$ is the slope length steepness factor (dimensionless); $C$ is the cover management factor (dimensionless, ranging between 0 and 1); and $P$ is practices factor (dimensionless, ranging between 0 and 1 ).

In this study, the Universal Soil Loss Equation (USLE) was combined with GIS technologies to estimate the potential soil loss from areas within the Oued El Makhazine watershed, generate soil erosion severity maps, and analyze areas of critical soil erosion conditions which claim urgent need for convenient conservation measures and land management.

\subsubsection{Rainfall Erosivity Factor $(R)$}

The erosivity factor $(R)$ in the USLE equation is accounted for by the rainfall-runoff, it is considered as a driver of soil erosion processes. The $R$ factor represent the effect of raindrop impact and also shows the amount and rate of runoff associated with precipitation events, it is defined as the product of kinetic energy and the maximum 30 minute intensity and shows the erosivity of rainfall events [17].

Rainfall data of 10 years (2004-2014) was obtained from the Loukkos Hydraulic Basin Agency and imported into GIS environment since all the weather stations had geographical coordinates. Annual and monthly rainfall data of Oued El Makhazine watershed was used to calculate the $R$-factor in this study.

The rainfall erosivity values for the different stations were used to interpolate a rainfall erosivity surface using the Inverse Distance Weighted (IDW) interpolation method in ArcGis environment to generate a raster map for $R$ factor. The IDW interpolation method was selected because rainfall erosivity sample points are weighted during interpolation such that the influence of rainfall erosivity is most significant at the measured point and decreases as distance increases away from the point. The IDW interpolation method is based on the assumption that the estimated value of a point is influenced more by nearby known points than those farther away [18] [19].

The Equation (2), below developed by Wischmeier and Smith [17] and modified by Arnoldus [20] was used in the computation:

$$
R=\sum_{i=1}^{12} 1.735 \times 10\left(1.5 \times \log _{10}\left(\frac{P_{i}^{2}}{P}\right)-0.08188\right)
$$

where $R$ is the rainfall erosivity factor $\left(\mathrm{MJ} \cdot \mathrm{mm} \cdot \mathrm{ha}^{-1} \cdot \mathrm{h}^{-1} \cdot \mathrm{y}^{-1}\right), P_{i}$ is the monthly rainfall (mm), and $P$ is the annual rainfall $(\mathrm{mm})$.

The mean values of $R$ factor range from $74.63 \mathrm{MJ} \cdot \mathrm{mm} \cdot \mathrm{ha}^{-1} \cdot \mathrm{h}^{-1} \cdot \mathrm{y}^{-1}$ to $116.11 \mathrm{MJ} \cdot \mathrm{mm} \cdot \mathrm{ha}^{-1} \cdot \mathrm{h}^{-1} \cdot \mathrm{y}^{-1}$ (Figure 3(a)), approximately $76.82 \%$ of the rainfall erosivity factor $\mathrm{R}$ ranges between $74.63 \mathrm{MJ} \cdot \mathrm{mm} \cdot \mathrm{ha}^{-1} \cdot \mathrm{h}^{-1} \cdot \mathrm{y}^{-1}$ and 96.59 $\mathrm{MJ} \cdot \mathrm{mm} \cdot \mathrm{ha}^{-1} \cdot \mathrm{h}^{-1} \cdot \mathrm{y}^{-1}$.

\subsubsection{Soil Erodibility Factor $(K)$}

The soil erodibility factor $(K)$ relate to the average long-term soil and soil profile response to the erosive power associated with rainfall and runoff. It is also considered to represent the rate of soil loss per unit of rainfall erosion index for a specific soil. The USLE model utilizes the technique proposed by Wischmeier [21] to measure the $K$ factor of a soil type.

The specific methodology concerns many properties of soil such as gain size (silt, clay and sand), organic matter content, soil structure and soil permeability [21] [22].

The soil samples collected from Oued El Makhazine watershed were analyzed in soil laboratory of National Institute of Agricultural Research of Settat. For each sample the particle size analysis was performed in five classes (sand, very fine sand, silt, very fine silt, and clay) using Robinson's pipette method [23]. Organic carbon was measured by the Walkley-Black wet dichromate oxidation [24] and converted to organic matter by multiplying it by 1.724. Soil permeability code was obtained from the National Soils Handbook No. 430 (USDA, 1983) [25] and Soil structure code was determined using Soil Textural Pyramid [26].

To calculate the soil erodibility, the formula of Wischmeier and Smith [17] was used.

$$
K=\frac{2.173 \times\left(2.1 \times M^{1.14} \times\left(10^{-4}\right) \times(12-a)+3.25 \times(b-2)+2.5 \times(C-3)\right)}{100}
$$

where $K$ is the soil erodibility factor ( $\left.\mathrm{t} \cdot \mathrm{ha} \cdot \mathrm{h} \cdot \mathrm{ha}^{-1} \cdot \mathrm{MJ}^{-1} \cdot \mathrm{mm}^{-1}\right), M$ is the particles percentage (\% of very fine sand $+\%$ of silt $\mathrm{x}(100 \%$ clay)), $a$ is the organic matter content (\% C x 1.724), $b$ is the soil structure and $c$ is soil permeability. 
The analysis showed that $72 \%$ of samples had clay texture, $18 \%$ Sandy clay loam and $10 \%$ Clay loam texture.

Erodibility is low for clay rich soils with a low shrink swell capacity, as clay particles mass together into larger aggregates that resist detachment and transportation [27].

Organic matter content varies from the lowest of $1.37 \%$ up to the highest of $4.57 \%$. The permeability of Oued El Makhazine watershed is very low, a result that was observed in numerous publications [28]-[30] that the presence of clay decreases the level of soil permeability.

The result (Figure 3(b)) shows that Oued El Makhazine watershed has soil erodibility, ranges from 0.24 to 0.85 , the watershed has a moderate to severe soil erodibility with $71.26 \%$ of the area ranges between 0.68 $\mathrm{t} \cdot \mathrm{ha} \cdot \mathrm{h} \cdot \mathrm{ha}^{-1} \cdot \mathrm{MJ}^{-1} \cdot \mathrm{mm}^{-1}$ and $0.85 \mathrm{t} \cdot \mathrm{ha} \cdot \mathrm{h} \cdot \mathrm{ha}^{-1} \cdot \mathrm{MJ}^{-1} \cdot \mathrm{mm}^{-1}$.

\subsubsection{Slope Length and Steepness Factor (LS)}

The $\mathrm{L}$ and $\mathrm{S}$ factors in USLE reflect the effect of topography on erosion. It has been demonstrated that increases in slope length and slope steepness can produce higher overland flow higher erosion [31]. Moreover, gross soil loss is considerably more sensitive to changes in slope steepness than to changes in slope length [32].

Therefore one of the key factors in soil loss is topography, especially when the ground slope exceeds a critical angle. Topography factor plays a major role in soil erosion since it dominates the surface run off rate.

The combined LS factor of the watershed was derived from Digital elevation model by means of ArcGis environment. The computation of LS requires factors such as flow accumulation and slope steepness.

The flow accumulation and slope steepness were computed from the DEM using ArcGIS Spatial analyst extension.

The Equation (4), was adopted to calculate LS factor as proposed by Moore and Burch [33] [34].

$$
L S=\frac{(\text { Flowaccumulation } \times \text { Cellsize })^{0.4}}{22.13} \times \frac{(\text { sin slope })^{1.3}}{0.0896}
$$

where flow accumulation denotes the accumulated upslope contributing area for a given cell, LS = combined slope length and slope steepness factor, cell size = size of grid cell (for this study $30 \mathrm{~m}$ ) and sin slope = slope degree value in sin.

The LS factor value in the study area varies from 0 to 22 (Figure 4(a)). The Majority of the study area (77.72 \%) has LS value ranges between 0 and 6.29.

\subsubsection{Cover Management Factor $(C)$}

The coverage factor ranges from 0 (full soil coverage) to 1(no soil coverage) [17].

$C$ factor represents the effect of soil disturbing activities, plants, crop sequence and productivity level, soil cover and subsurface bio-mass on soil erosion [35]. Natural vegetation plays a predominant role in reducing water erosion [36].

Vegetation indices such as the NDVI (Normalized Difference Vegetation Index) are quantitative measures, based on vegetation spectral properties that attempt to measure biomass or vegetative vigor [37]. As an indirect estimate of vegetative density, a Normalised Difference Vegetation Index (NDVI), which approximates chlorophyll density, was calculated for the study area using Landsat TM images with a spatial resolution of 30 meter.

Satellite imagery acquired during the rain season are more adapted for this application given that soil erosion is most active and vegetation cover is at its peak during this season.

$$
N D V I=\frac{N I R-R E D}{N I R+R E D}
$$

where NIR is light intensity in the near-infrared, and $R E D$ is light intensity in the red band.

This index is an indicator of the energy reflected by the Earth related to various cover type conditions. When the measured spectral response of the earth surface is very similar to both bands, the NDVI values will approach zero. A large difference between the two bands results in NDVI values at the extremes of the data range.

Photosynthetically active vegetation presents a high reflectance in the near IR portion of the spectrum (0.76 $0.90 \mu \mathrm{m})$, in comparison with the visible portion Red band $(0.63-0.69 \mu \mathrm{m})$; therefore, NDVI values for photosynthetically active vegetation will be positive. Areas with or without low vegetative cover (such as bare soil, urban areas), as well as inactive vegetation (unhealthy plants) will usually display NDVI values fluctuating be- 
tween -0.1 and +0.1 . Clouds and water bodies will give negative or zero values.

The following formula was used to generate a $C$ factor surface (Figure 4(b)) from NDVI values [38]-[40]:

$$
C=e^{-a\left(\frac{N D V I}{b-N D V I}\right)}
$$

where a and $b$ are unitless parameters that determine the shape of the curve relating to NDVI and C factor. According to Van der Knijff an a-value of 1 and a b-value of 2 seem to give reasonable results [38].

\subsubsection{Conservation Practice Factor $(P)$}

The $P$ factor is the soil-loss ratio with a specific support practice to the corresponding soil loss with up and down slope tillage [41]. Usually, the conservation practice factor corrects the USLE estimation for management and tillage practices that protect the soil from erosion.

In the present study the $P$ factor map was derived from the land use/land cover and support factors. The values of $P$ factor ranges from 0.55 to 1 (Figure 4(c)), in which the high value is assigned to areas with no conservation practices; the minimum values correspond to built-up-land and plantation area with strip and contour cropping.

\section{Results and Discussion}

\section{Average Annual Soil Loss}

The data layers (maps) extracted for $K, L S, R, C$, and $P$ factors of the USLE model were integrated using Equation (1) within the raster calculator option of the ArcGIS spatial analyst in order to quantify, evaluate, and generate the maps of soil erosion risk and severity for Oued El Makhazine watershed.

Generally, if the estimated (A) value is high, it means a higher rate of sediment yield, while a lower value denotes a lower rate of sediment yield [42].

The Oued El Makhazine watershed was classified into five soil erosion risk categories (Figure 4(d)). The area and proportion of soil erosion risk classes are illustrated in Table 1. The maximum and minimum losses are respectively about $0 \mathrm{t} \cdot \mathrm{ha}^{-1} \cdot \mathrm{y}^{-1}$ and $735 \mathrm{t} \cdot \mathrm{ha}^{-1} \cdot \mathrm{y}^{-1}$, about $65.26 \%\left(1575 \mathrm{~km}^{2}\right)$ of the watershed ranges between 0 $\mathrm{t} \cdot \mathrm{ha}{ }^{-1} \cdot \mathrm{y}^{-1}$ and $95 \mathrm{t} \cdot \mathrm{ha}^{-1} \cdot \mathrm{y}^{-1}$.

The results shows that the Oued El Makhazine watershed is exposed to a very high erosion risk, the highest

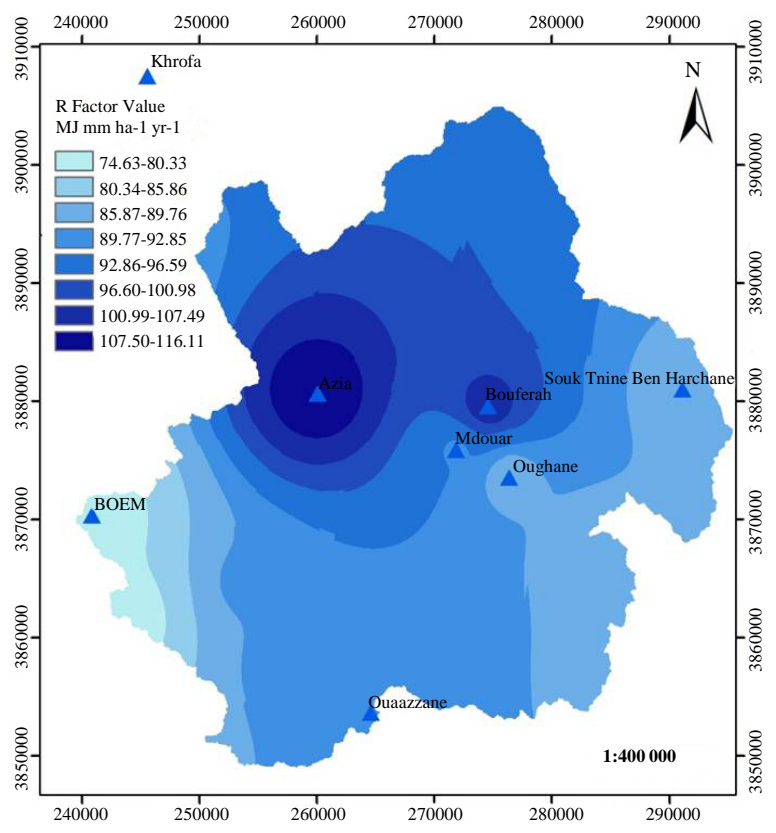

(a)

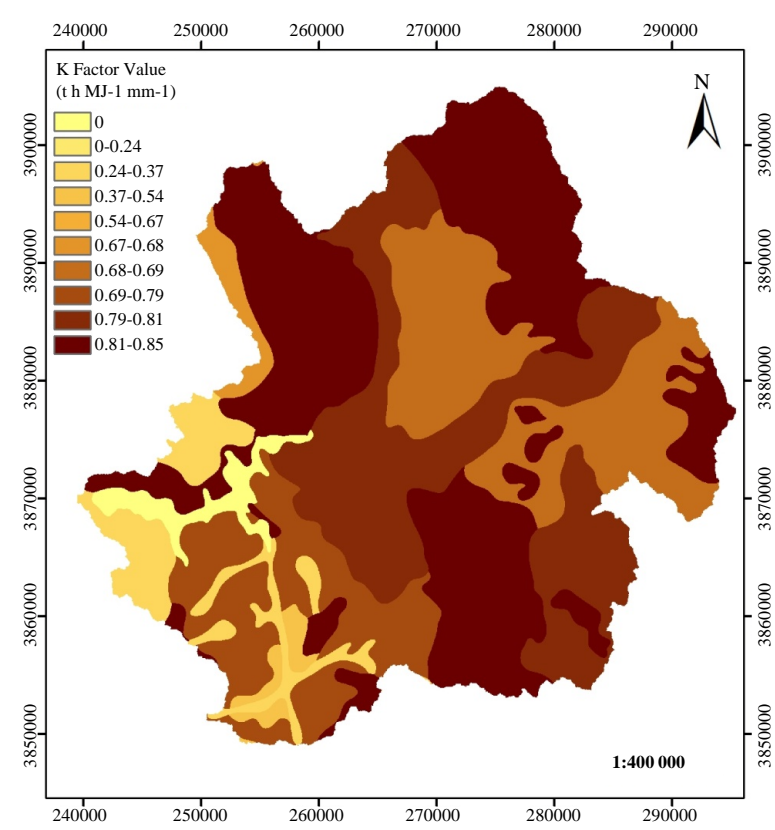

(b)

Figure 3. (a) Erosivity factor, (b) Soil erodibility factor. 


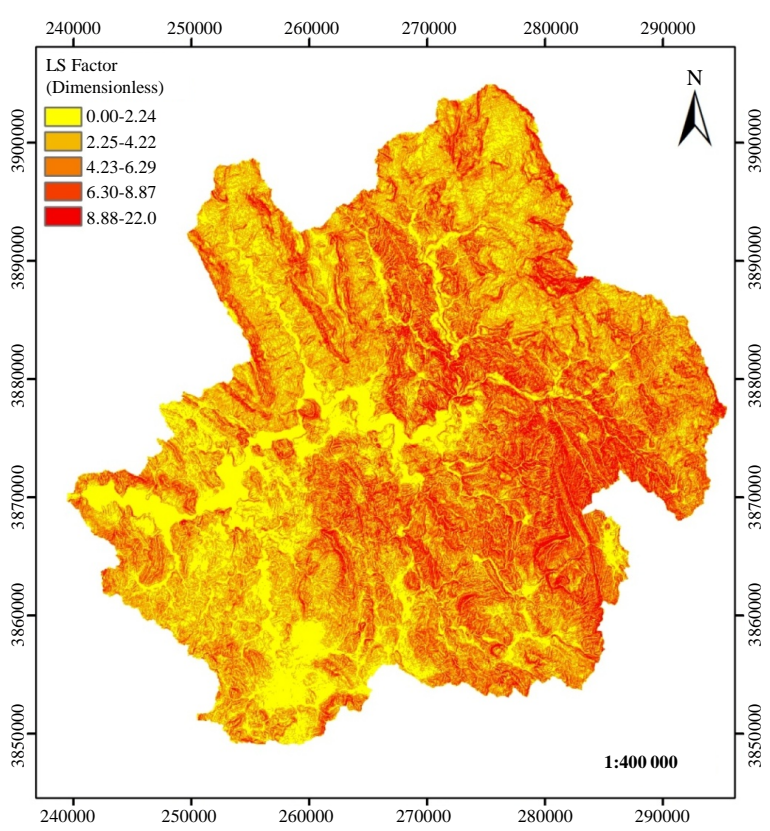

(a)



(c)

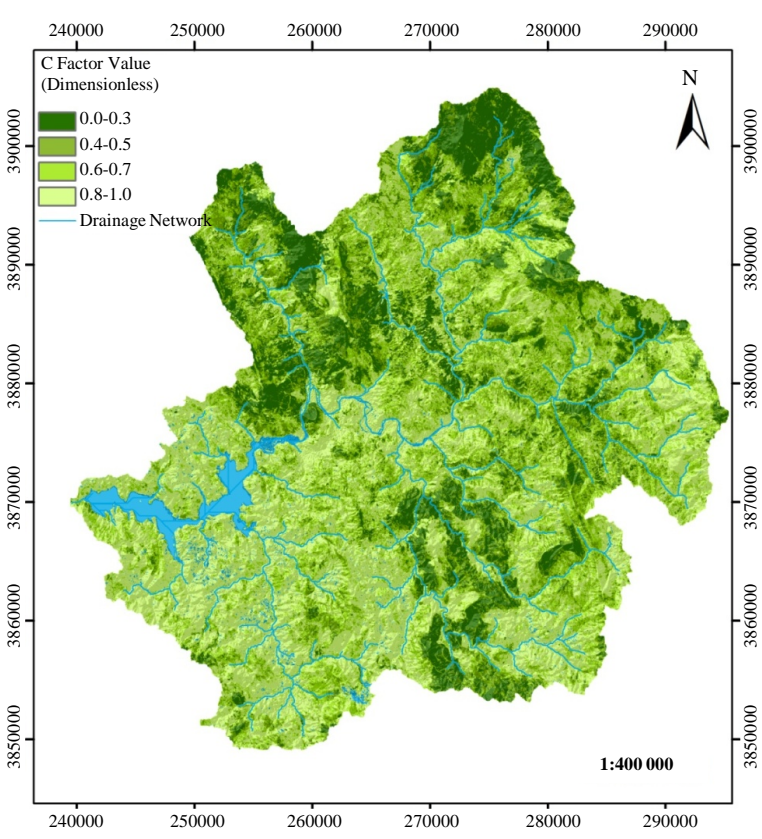

(b)



(d)

Figure 4. (a) Topography factor, (b) Land cover factor, (c) Conservation practice factor, (d) Annual soil loss.

Table 1. Classification of soil loss of Oued El Makhzine watershed according to area.

\begin{tabular}{ccc}
\hline Soil Loss $\left(\mathrm{t} \cdot \mathrm{ha}^{-1} \cdot \mathrm{y}^{-1}\right)$ & Area $\left(\mathrm{km}^{2}\right)$ & Area (\%) \\
\hline $0-43$ & 798.81 & 33.09 \\
$44-95$ & 776.47 & 32.17 \\
$96-153$ & 491.74 & 20.37 \\
$154-228$ & 263.58 & 10.92 \\
$229-735$ & 83.40 & 3.45 \\
Total & 2414 & 100 \\
\hline
\end{tabular}


soil loss values are spatially correlated with the steepest slopes.

\section{Conclusions}

USLE is a straightforward and empirically based model that has the ability to predict long term average annual rate of soil erosion on slopes using data on rainfall pattern, soil type, topography, crop system and management practices. In the present research, annual soil erosion rate map is generated for Oued El Makhazine watershed, a mountainous area, which represents the first reliefs of the Rif mountain chain. Several data sources are used for the generation of USLE model input factors and are stored as raster GIS layers in ArcGis environment.

The combination of the model USLE with GIS techniques has shown divers advantages, specifically the resulats of each factor involved in the erosion process. GIS allows rational management of a multitude of data, with respect to the various factors responsible of land degradation; in fact, in this case, it allows us to conclude that the primary factor responsible of the degradation of Oued El makhazine watershed is the steep and the slope morphologies, the soil erodibility and the vegetation cover comes in the second place. GIS also simplifies and facilitates the enrichment continuous updating of the database.

The intensiveness of the rainfall coupled with steep gradient slopes causes severe erosion runoff in the study area. The result of this high runoff and soil detachment is considered as the main agent for the high rate of soil erosion at Oued El Makhzine watershed.

There is an urgency to take into consideration this soil loss by all possible ways so as to reduce the existing amount of soil loss and to raise watershed rehabilitation and productivity.

Finally, the present investigation has demonstrated that GIS techniques are low cost tools and simple for modeling and mapping soil erosion, with the purpose of evaluating erosion potential risk for Oued El Makhazine watershed.

\section{References}

[1] Aiello, A., Adamo, M. and Canora, F. (2015) Remote Sensing and GIS to Assess Soil Erosion with RUSLE3D and USPED at River Basin Scale in Southern Italy. Catena, 131, 174-158. http://dx.doi.org/10.1016/j.catena.2015.04.003

[2] Foster, G.R. and Meyer, L.D. (1972) A Closed-Form Soil Erosion Equation for Upland Areas In: Shen, H.W., Ed., Proceeding of Sedimentation Symposium to Honor Prof. H. A. Einstein, Vol. 12, Colorado State University, Fort Collins, 1-19.

[3] Kuznetsov, S., Feudel, U. and Pikovsky, A. (1998) Renormalization Group for Scaling at the Torus-Doubling Terminal Point. Physical Review, 57, 1585-1590. http://dx.doi.org/10.1103/physreve.57.1585

[4] Chevalier, J.J., Pouliot, J., Thomson, K. and Boussema, M.R. (1995) Systèmes d'Aide à la Planification Pour la Conservation des Eaux et des Sols (Tunisie). Systèmes d’Information Géographique Utilisant les Données de Télédétection. Actes du Colloque Scientifique International, Hammamet, Tunisie, 4-12.

[5] Lahlou, A. (1977) Specific Degradation of Watershed in Morocco. Report $n^{\circ} 1000$, Ministry of Equipment and National Promotion, Water Direction, Exploitation Division, Water Management Service, Rabat, 1977.

[6] Ait Fora, A. (1995) Modélisation Spatiale de l'Erosion Hydrique dans un Bassin Versant du Rif Marocain: Validation de l’Approche Géomatique par la Sédimentologie, les Traceurs Radio-Actifs et la Susceptibilité Magnétique des Sédiments. PhD Thesis, Sherbrooke University, Quebec.

[7] Tahri, M., Merzouk, A., Lamb, H.F. and Maxted, R.W. (1993) Etude de l'Erosion Hydrique dans le Plateau d'Imelchil dans le Haut Atlas Central. Utilisation d'un SIG. Geo Observateur, 3, 51-60.

[8] Merzouki, T. (1992) Diagnostic de l’envasement des grands barrages marocains. Revue Marocaine du Génie Civil, 38, 46-50.

[9] High Commission for Water, Forest and Combating Desertification (1996) National Watershed Management Plan.

[10] Namr, K.L. and Mrabet, R. (2004) Influence of Agricultural Management on Chemical Quality of a Clay Soil of Semi-Arid Morocco. Journal of African Earth Sciences, 39, 485-489. http://dx.doi.org/10.1016/j.jafrearsci.2004.07.016

[11] Belkheri, A. (1988) Conséquences de la dégradation des bassins versants sur les retenues de barrages. Rapport du Séminaire National sur l'aménagement des bassins versants "Diagnostic de la situation actuelle”, MARA., T.P., PNUD/FAO, 18-28 Janvier, Rabat, 23.

[12] Food and Agriculture Organization of the United Nations (2005) National Soil Degradation Maps. Soil Degradation Map of Slovenia. FAO/AGL, GLASOD, Last Update.

[13] Heusch, B. (1970) Prerif Erosion. A Quantitative Study of Water Erosion in the Marly Hills of the Western Prerif. Di- 
rectory of Forest Research of Morocco, 129-176.

[14] Sadiki, A., Bouhlassa, S., Auajjar, J., Faleh, A. and Macaire, J.J. (2004) Use of GIS for the Evaluation and Mapping of Erosion Risk by the Universal Soil Loss Equation in the Eastern Rif (Morocco): Boussouab Watershed Case Study. Scientific Institute Bulletin, Rabat, Earth Sciences Series, 26, 69-79.

[15] Wahby, Y. (2008). Modeling the Water Resources Management Model MIKE BASIN and Development of a GIS in the Loukkos Basin. Draft Report of Graduates, Mohammed V University, Mohammadia School of Engineers, Rabat.

[16] Renard, K.G., Foster, G.R., Weesies, G.A., McCool, D.K. and Yoder, D.C. (1997) Predicting Soil Erosion by Water: A Guide to Conservation Planning with the Revised Universal Soil Loss Equation (RUSLE). USDA Agricultural Handbook No. 703, 126-131.

[17] Wischmeier, W.H. and Smith, D.D. (1978) Predicting Rainfall Erosion Losses. A Guide to Conservation Planning. The USDA Agricultural Handbook No. 537, Maryland.

[18] Weber, D. and Englund, E. (1992) Evaluation and Comparison of Spatial Interpolators. Mathematical Geology, 24, 381-391. http://dx.doi.org/10.1007/BF00891270

[19] Weber, D. and Englund, E. (1994) Evaluation and Comparison of Spatial Interpolators II. Mathematical Geology, 26, 589-603. http://dx.doi.org/10.1007/BF02089243

[20] Arnoldus, H.M.J. (1980) An Approximation of the Rainfall Factor in the Universal Soil Loss Equation. In: De Boodt, M. and Gabriels, D., Eds., Assessment of Erosion, John Wiley and Sons, New York, 127-132.

[21] Wischmeier, W.H., Johnson, C.B. and Cross, B.V. (1971) A Soil Erodibility Nomograph for Farmland and Cons- truction Sites. Journal of Soil and Water Conservation, 26, 189-193.

[22] Millward, A. and Mersey, J. (1999) Adapting the RUSLE to Model Soil Erosion Potential in a Mountainous Tropical Watershed. Catena, 38, 109-129. http://dx.doi.org/10.1016/S0341-8162(99)00067-3

[23] SSEW (1982) Soil Survey Laboratory Methods. Technical Monographs No. 6, Harpenden.

[24] Nelson, D.W. and Sommer, L.E. (1982) Total Carbon, Organic Carbon, and Organic Matter. In: Analysis, A.L., Ed., Methods of Soil, 2nd Edition, ASA Monograph, American Society of Agronomy, Madison, 539-579.

[25] USDA (1983) National Soil Survey Handbook. No. 430, US Department of Agriculture, USDA, Washington DC.

[26] Hashim, G.M. and Wan Abdullah, W.Y. (2005) Prediction of Soil and Nutrient Losses in a Highland Catchment. Water, Air and Soil Pollution: Focus, 5, 103-113. http://dx.doi.org/10.1007/s11267-005-7406-x

[27] ÓGeen, A.T., Elkins, R. and Lewis, D. (2006) Erodibility of Agricultural Soils with Examples in Lake and Mendocino Counties Oakland. University of California, Division of Agriculture and Natural Resources, Publication No. 8194.

[28] Bos, M.R.E. (1982) Prolific Dry Oil Production from Sands with Water Saturations in Excess of 50\%: A Study of a Dual Porosity System. The Log Analyst, 23, 17-23.

[29] Fuechtbauer, H. (1967) Influence of Different Types of Digenesis on Sandstone Porosity. Proceedings of the 7th World Petroleum Congress, 2, 353-368.

[30] Herron, M.M. (1994) Estimating the Intrinsic Permeability of Classic Sediments from Geochemical Data. Proceedings of the SPWLA 28th Annual Logging Symposium, 29 June-2 July 1987, London, 23.

[31] Haan, C.T., Barfield, B.J. and Hayes, J.C. (1994) Design Hydrology and Sedimentology for Small Catchments. Academic Press, San Diego, 588.

[32] McCool, D.K., Brown, L.C. and Foster, G.R. (1987) Revised Slope Steepness Factor for the Universal Soil Loss Equation. Transactions of the American Society of Agricultural Engineers, 30, 1387-1396. http://dx.doi.org/10.13031/2013.30576

[33] Moore, I.D. and Burch, G.J. (1986) Physical Basis of the Length Slope Factor in the Universal Soil Loss Equation. Soil Science Society of America, 50, 1294-1298. http://dx.doi.org/10.2136/sssaj1986.03615995005000050042x

[34] Moore, I.D. and Burch, G.J. (1986) Modeling Erosion and Deposition. Topographic Effects. Transactions of American Society of Agriculture Engineering, 29, 1624-1630. http://dx.doi.org/10.13031/2013.30363

[35] Prasannakumar, V., Vijith, H. and Geetha, N. (2011) Estimation of Soil Erosion Risk within a Small Mountainous Sub-Watershed in Kerala, India, Using Revised Universal Soil Loss Equation (RUSLE) and Geoinformation Technology. Geoscience Frontiers, 3, 209-215. http://dx.doi.org/10.1016/j.gsf.2011.11.003

[36] Kheir, R.B., Abdallah, C. and Khawlie, M. (2008) Assessing Soil Erosion in Mediterranean Karst Landscapes of Lebanon Using Remote Sensing and GIS. Engineering Geology, 99, 239-254. http://dx.doi.org/10.1016/j.enggeo.2007.11.012

[37] Agapiou, A. and Hadjimitsis, D.G. (2011) Vegetation Indices and Field Spectroradiometric Measurements for Validation of Buried Architectural Remains: Verification under Area Surveyed with Geophysical Campaigns. Journal of Applied Remote Sensing, 5, Article ID: 053554. http://dx.doi.org/10.1117/1.3645590 
[38] Van der Knijff, J.M., Jones, R.J.A. and Montanarella, L. (2000) Soil Erosion Risk Assessment in Europe. EUR 19044 EN, Office for Official Publications of the European Communities, Luxembourg, 34.

[39] Van der Knijff, J.M., Jones, R.J.A. and Montanarella, L. (1999) Soil Erosion Risk in Italy. EUR19022 EN, Office for Official Publications of the European Communities, Luxembourg, 54.

[40] Van Leeuwen, W.J.D. and Sammons, G. (2004) Vegetation Dynamics and Soil Erosion Modeling Using Remotely Sensed Data (MODIS) and GIS. Proceedings of the Tenth Biennial USDA Forest Service Remote Sensing Applications Conference, Salt Lake City, 5-9 April 2004.

[41] Renard, K.G., Foster, G.R., Weesies, G.A., McCool, D.K. and Yoder, D.C. (1997) Predicting Soil Erosion by Water: A Guide to Conservation Planning with the Revised Universal Soil Loss Equation (RUSLE). Agriculture Handbook No. 703, US Department of Agriculture, Washington DC, 1-251.

[42] Prasannakumar, V., Vijith, H., Geetha, N. and Shiny, R. (2011) Regional Scale Erosion Assessment of a Sub-Tropical High-Land Segment in the Western Ghats of Kera, South India. Water Resources Management, 25, 3715-3727. http://dx.doi.org/10.1007/s11269-011-9878-y 